\title{
INDIVIDU KOMUNIKATIF MENURUT JURGEN HABERMAS DALAM PERSPEKTIF FILSAFAT MANUSIA
}

\section{HABERMAS'S THEORY OF COMMUNICATIVE ACTION IN THE PERSPECTIVE OF HUMAN PHILOSOPHY}

\author{
Syahrul Kirom \\ IAIN Syekh Nurjati
}

syahrulkirom1984@syekhnurjati.ac.id

\begin{abstract}
ABSTRAK: Manusia adalah makhluk yang unik, yang selalu menampilkan eksistensinya melalui pemikiran dan rasional. Keunikan manusia yang seperti itu telah lama dinyatakan oleh Aristoteles, filsuf klasik, bahwa manusia adalah animal rationale. Rumusan yang seperti itu muncul dalam filsafat manusia. Akan tetapi, seiring dengan berjalannya waktu, filsafat manusia saat ini mengalami pergeseran dan lebih tertarik dalam upaya merumuskan manusia sebagai animal loquens (makhluk yang berbicara). Penelitian ini menggunakan pendekatan deskriptis-analitis. Metode yang digunakan adalah Hermeneutika untuk menafsirkan konsepsi pemikiran Jurgen Habermas tentang manusia sebagai objek materialnya. Sedangkan objek formalnya adalah filsafat manusia. Hasil penelitian ini menemukan bahwa ternyata manusia tidak hanya berkutat pada wilayah refleksi diri atau makhluk yang berpikir saja. Namun manusia dapat berkomunikasi dengan yang lain. Individu manusia menemukan keunikan dan kepribadian jika mampu bersikap komunikatif, sikap komunikatif ini terlahir dari rasionalitas yang digagas oleh Jurgen Habermas. Keberadaan Individu komunikatif inilah yang menjadi hakekat manusia dalam kajian filsafat manusia. Eksistensi manusia menjadi ada, jika manusia itu mampu bersikap komunikatif. Komunikatif dalam artian untuk melakukan kritik-kritik atas keberadaan masyarakat modern. Dalam konteks manusia modern, adanya identitas ego memiliki peran yang sangat siginifikant sebagai upaya melakukan komunikasi antar pribadi dan dengan manusia yang lain. Individu komunikatif inilah yang menjadi bagian dari individu diskursif dalam menuju masyarakat komunikatif.
\end{abstract}

Kata Kunci: Makhluk Rasional' , Individu Komunikatif2, Identitas Ego33, Filsafat Manusia4.

ABSTRACT: Humans are unique creatures, who always show their existence through rational thinking. Aristotle, the classical philosopher, once stated the uniqueness of humans, that humans are the animal rationale. This assumption appears in human philosophy. However, human philosophy is currently experiencing a shift and is more interested in defining humans as animal loquens (creatures that speak). This research uses a descriptive-analytical approach. The method used is hermeneutics to interpret Jurgen Habermas' conception of thinking about man as his material object. Meanwhile, the formal object is human philosophy. The results of this study found that humans are not only concerned with the area of self-reflection or thinking creatures. But humans can communicate with others. The human individual finds his uniqueness and personality if he is able to be communicative, this communicative attitude was born from rationality initiated by Jurgen Habermas. The existence of this communicative individual is the essence of humans in the study of human philosophy. Human existence comes into being, if humans are able to be communicative. Communicative in the sense of criticizing the existence of modern society. In the context of modern humans, the existence of ego identity has a very significant role as an effort to communicate between individuals and with other humans. This communicative individual becomes part of the discursive individual in the communicative society

Keyword: Rational Beings', Communicative Individuals², Ego Identity ${ }^{3}$, Human Philosophy ${ }^{4}$. 


\section{A. PENDAHULUAN}

Dalam mempelajari filsafat manusia, tentunya ada pertanyaan mendasar yang perlu diajukan secara umum, antara lain adalah, siapakah manusia? apa itu manusia? dimanakah keunikan manusia dengan manusia yang lain? dari mana? dan ingin ke mana manusia hidup di dunia ini? Pertanyaan-pertanyaan tersebut muncul di tengah kegelisahan kehidupan manusia dalam mempertanyakan eksistensinya. Untuk menjawab itu semua, maka tiap individu manusia harus mampu merefleksikan diri sendiri. Upaya refleksi sangat penting sekali untuk memberikan penghayatan atas dirinya, sehingga diperoleh pengetahuan secara terang benderang mengenai diri individu ini. Manusia dengan segala kepemilikannya dalam tubuh, baik itu roh, akal dan segala atribut yang hadir dalam dirinya, harus mampu mengetahui hakekat manusia hidup di dunia.

Pertanyaan-pertanyaan mengenai "hakekat manusia" telah lama dan banyak dikupas oleh beberapa pemikir dan filsuf klasik di Barat hingga filsuf klasik di Timur. Pertanyaan-pertanyaan tersebut hanya bisa dijawab oleh manusia yang berpikir, dan berpikir tentang dirinya sendirinya. Karena itu, usaha manusia dalam menemukan makna kehidupannya ditentukan oleh bagaimana cara manusia dalam berpikir, atau istilahnya manusia rasional. Pandangan mengenai hal itu telah lama dinyatakan oleh Aristoteles, dan filsuf klasik lainnya, bahwa manusia adalah animal rationale.

Fakta yang perlu kita sadari saat ini adalah setiap zaman telah berubah dari zaman klasik, hingga zaman modern. Oleh karena itu, pemahaman mengenai eksistensi manusia dalam menempatkan diri individu mesti juga dapat berubah suatu saat. Setiap perubahan yang terjadi selalu dimulai dari kenyataan bahwa cara-cara yang lama sudah tidak sesuai lagi dengan tuntutan zaman. Perubahan-perubahan yang terjadi saat ini, itu mengisyaratkan suatu perubahan pada diri manusia juga, maka pemikiran-pemikiran baru yang sesuai dengan masanya tentang hakekat manusia pun dibutuhkan. Oleh karena itu, seiring dengan berjalannya waktu, filsafat manusia saat ini mengalami pergeseran dan lebih tertarik dalam upaya merumuskan manusia sebagai animal loquens (makhluk yang berbicara) ${ }^{1}$. Keunggulan manusia sangat nyata dalam hal bahasa. Manusia harus belajar berbicara. Dengan demikian, komunikasi sangat ditekankan

\footnotetext{
${ }^{1}$ Adelbert Snijdelrs, OFM Cap, Antropologi Filsafat Manusia Paradoks dan Seruan, Kanisius, Yogyakarta, 2004, hlm : 17.
} 
dalam kehidupan manusia dengan manusia yang lain. Eksistensi manusia di dunia itu ada ketika manusia mampu berbicara atau berkomunikasi.

Dengan berpijak pada asumsi itulah, dalam tulisan ini, penulis ingin mengambil dari sudut pandang pemikiran Jurgen Habermas mengenai eksistensi manusia sebagai topik kajian dari filsafat manusia². Manusia sebagai individu dan makhluk sosial, tentunya harus mampu mencapai komunikasi yang satu dengan yang lain, agar manusia itu mampu menemukan eksistensinya di tengah kehidupan bermasyarakat. Seperti filsuf klasik pada umumnya, Jurgen Habermas pun mempertanyakan siapa manusia itu, dan hakekat manusia dalam hubunganya dengan makhluk lainnya.

\section{B. METODE PENELITIAN}

Peneliti menggunakan penelitian kepustakaan (library research), yakni mengkaji sejumlah bahan pustaka yang bertujuan untuk mendeskripsikan dan atau merekonstruksi wacana-wacana sosial tertentu secara obyektif dan akurat. Bahan-bahan kepustakaan yang dikaji adalah pemikiran dari filsuf klasik yaitu Jurgen Habermas. Tokoh Jurgen Habermas dipilih karena ia memiliki perhatian yang besar terhadap filsafat manusia. Metode ini dilakukan dengan melakukan pengumpulan data-data pustaka yang terkait objek penelitian. Selain itu dilakukan telaah atas bacaan dan menganalisis dengan menggunakan perspektif sesuai judul penelitian. Tahap selanjutnya dari metode ini yaitu menyusun data dalam tulisan secara deskriptif analitis untuk menemukan hasil dari penelitian.

\section{HASIL DAN PEMBAHASAN}

\section{Sejarah Kehidupan Jurgen Habermas}

Jurgen Habermas saat ini merupakan salah seorang dari filsuf yang paling berpengaruh dan terkemuka di dunia. Dengan memadukan tradisi pemikiran kontinental dan Anglo-Amerika, ia telah melibatkan diri dalam debat dengan pelbagai pemikir lainnya yang saling bertentangan seperti Hans Georg Gadamer, John Piaget, Laurence Kohlberg, Michel Foucalt, John Rawls dan Jacques Derrida, Immanuel Kant, John Rawls.

\footnotetext{
2 Eksistensi, dalam bahasa latin existere (muncul, ada, timbul, memiliki keberadaan aktual), memiliki aktualitas (ada), eksistensi adalah segala sesuatu (apa saja) yang dialami, menekankan bahwa sesuatu itu ada. Lihat Lorens Bagus, Kamus Filsafat, Gramedia, Jakarta, 2000, hlm: 183.
} 
Karya tulisanya yang maha luas membicarakan secara elastis topik-topik dari teori sosial-politik, sampai estetika, epistemologi dan bahasa sampai filsafat agama, dan ide-idenya secara signifikan telah mempengaruhi tidak hanya filsafat tetapi juga pemikiran politik-hukum, sosiologi-studi-studi komunikasi, teori argumentasi dan retorika, psikologi perkembangan dan teologi. Lebih lanjut, ia telah menjadi sosok paling menonjol di Jerman sebagai intelektual, yang mengkomentari isu-isu kontroversial di negara Jerman.

Habermas di Lahirkan di Gummersbach tahun 1929 di Jerman. Di universitas Kota Gottingen ia belajar kesusasteraan Jerman, sejarah dan filsafat (antara lain pada N. Hartmann) dan juga mengikuti kuliah di bidang Psikologi dan ekonomi ${ }^{3}$. Ia mempelajari Filsafat di Universitas Got I Tingen and Bonn dan mengawali karir akademisinya sebagai asisten Theodor Adorno, seorang filsuf Jerman terkemuka di Institute for Social Research. Jurgen Habermas bergabung dengan Institut fur Sozial forschung pada tahun 1956, yaitu lima tahun setelah Institut itu didirikan kembali di bawah kepemimpinan Adorno. Waktu ia masih berusia 27 Tahun dan telah menyelesaikan program Doktoralnya dalam bidang filsafat dua tahun sebelumnya di University Bonn, dengan disertasi berjudul das Absolut und die Geschit ${ }^{4}$.

Pada awal tahun 1960-an Habermas sangat populer dikalangan mahasiswa Jerman dan oleh beberapa golongan dianggap sebagai ideolog mereka, khususnya beberapa golongan SDS (Sozialistische Deutsche Studentenbud). Tetapi ketika aksi-aksi mahasiswa mulai melewati batas dengan menggunakan kekerasan. Habermas tidak segan mengemukakan kritiknya. Pada Tahun 1960-an dan 1970-an Habermas dan Universitas Fraknfrut dan sempat menjabat sebagai direktur Max Planck Institute di Stranberg tempat di mana ia diangkat sebagai profesor filsafat hingga pensiunnya tahun 1994. Jurgen Habermas sangat menekankan signifikansi rasionalitas dalam pemikiran Filsafatnya (Jozef Niznik dan John T Sanders, 1996: vii). Dalam hal ini sumbangan pemikirannya terhadap perkembangan filsafat kontemporer sangat berarti dan berguna sekali.

\footnotetext{
${ }^{3} \mathrm{~K}$ Bertens, Filsafat Barat Kontemporer Inggris-Jerman, Gramedia, Jakarta, 2002, hlm: 236.

${ }^{4}$ F Budi Hardiman, Kritik Ideologi, Menyingkap Pertautan Pengetahuan dan Kepentingan Bersama Jurgen Habermas, Kanisius, Yogyakarta, 2009, hlm: 82.
} 


\section{Manusia sebagai Individu Diskursif}

Sejauh yang penulis pahami mengenai gagasan Habermas mengenai manusia, bahwa individu itu hadir di tengah-tengah masyarakat sebagai individu yang diskursif. Ide dasar itulah yang melandasi Jurgen Habermas sampai pada masyarakat komunikatif di ruang diskursif secara ideal. Dalam membicarakan pemikiran Habermas ini, tentunya kita harus menengok tentang sejarahnya. Pemikiran Habermas ini bertitik tolak dari Max Horkheimer dalam mengembangkan pemikirannya mengenai masyarakat kritis, sebagai upaya kritik terhadap masyarakat modern dan masyarakat plural dengan cara praksis dan emansipatoris untuk menuju perubahan sosial..

Habermas sebagai pembaharu dalam madzhab Frankfrut ini dengan tujuan meneruskan proyek teori kritis menawarkan sebuah paradigma baru. Tentunya, paradigma ini berkaitan dengan siapa manusia dan hakekat manusia. Habermas menawarkan paradigma komunikasi. Individu diskursif, adalah individu yang mampu merefleksikan dirinya dengan sebuah dialog atau komunikasi dengan yang lain.

Melalui paradigma komunikasi itu, yang menekankan pada rasionalitas, ia menjelaskan bahwa rasionalitas adalah kemampuan berpikir logis dan analitis-lebih sekedar kalkulasi strategis bagaimana mencapai beberapa tujuan yang telah dipilih. Alih-alih, rasionalitas merupakan sebentuk "tindakan komunikatif yang diorientasikan untuk mencapai kesepakatan atau konsensus dengan orang lain. Jadi, menurutnya adalah suatu hal yang sangat penting bahwa dalam menggunakan bahasa berarti kita berpartisipasi di dalam apa yang disebut Habermas suatu "situasi pembicaraan yang ideal" atau "komunikasi dialogis-emansipatoris bebas kekuasaan"

Komunikasi merupakan titik tolak dari gagasan Habermas, dalam mengatasi kebuntuan. Dengan pendekatan komunikasi ini, Habermas memandang, bahwa eksistensi manusia pada dasarnya adalah makhluk sosial, yang di tentukan oleh tindakan manusia secara praksis. Praksis ini merupakan tindakan yang berdasar pada rasio dan kritis. Praksis dipahami sebagai "komunikasi", bukan sebagai kerja. Dengan menggunakan paradigma komunikasi, individu-individu akan menemukan eksistensi lewat kehadiran manusia yang lainnya.

Individu-individu diskursif adalah manusia-manusia yang mampu mengkomunikasikan dirinya dengan yang lain, bila individu-individu tak mampu mengkomunikasikan dengan makhluk lainnya, berarti manusia ini belum mampu 
berpikir secara rasionalitas, sebagai manusia yang memiliki bahasa untuk alat komunikasi.

Dalam pandangan Habermas, individu pada dasarnya makhluk sosial, sosial dalam arti mengkomunikasikan dengan yang lain. sehingga menjadikan masyarakat komunikatif yang universal. Melainkan, juga individu adalah personaliti sebab individu merupakan bagian dari kelompok. Karena individu mengambil tempat dalam bagian kelompok masyarakat sehingga dituntut untuk selalu bertindak ${ }^{5}$. Pertanyaan secara filosofis adalah apa yang dimaksudkan dengan Habermas mengenai hakekat manusia? Jawabnya, ketika individu-individu secara diskursif mampu mendialogkan dirinya dengan orang lain. Inilah salah satu karakter dan keunikan manusia dibanding dengan makhluk lainnya. Karena manusia terlahir dengan akal pikiran sehingga dituntut untuk menggunakan rasionalitas komunikatif sebaga cara membangun relasi dengan yang lain, dalam upaya mengkritisi modernitas. Modernitas itu cenderung mementingkan diri sendiri, karena itu, upaya yang harus dikerjakan adalah menjalin komunikasi dengan yang lainnya, untuk menemukan konsensus-konsensus.

Habermas, mencoba menggali hakikat manusia sebagai makhluk komunikatif. Manusia akan menjadi manusia tatkala mampu mampu berhubungan dengan lingkungan sekitar. Itulah inti dari hakekat manusia sebagai mahkluq yang berbicara atau komunikatif. Landasan itu muncul berpijak dari teori kritis, ketika manusia berhubungan dengan lingkungan dan masyarakat, yakni berkaitan dengan kerja dan komunikatif. Kedua hal itu tersebut antara kerja dan komunikatif disebut Habermas dengan praksis.

Pertama, berkaitan dengan kerja. Tindakan praksis muncul dilandasi oleh rasio tertentu. kerja dilandasi oleh rasio instrumental, yang mana tindakan instrumental itu mengarahkan pada tindakan yang sesuai dengan tujuan atau sasaran. Tindakan atas sasaran itu terbagi atas tindakan instrumental untuk menguasai alam dan tindakan strategis yang diarahkan pada manusia.

Kedua, berkaitan dengan komunikasi, pada tataran komunikasi. Itu dilandasi oleh rasio komunikatif. Komunikasi itu dilandasi oleh rasio komunikatif yang mengarahkan tindakan demi pemahaman (understanding). Habermas mengatakan

\footnotetext{
${ }^{5}$ Jurgen Habermas, The Theory of Communicative Action Volume 2 Lifeworld and System: A Critique of Functionalist Reason, Translated by Thomas McCarthy, Beacon Press, Boston, 1987, hlm:24.
} 
tindakan komunikasi adalah tindakan dasar manusia terhadap sesamanya, dengan tujuan untuk mencapai pemahaman terhadap orang lain ${ }^{6}$.

Dari kedua hal, tersebut, yang pertama bertujuan untuk mencapai kesuksesaan atau tujuan, sedangkan, pada kedua aspek komunikasi ini lebih menekankan pada upaya timbal balik dan saling memahami di antara individu satu dengan individu yang lain. sehinggai diharapkan bisa mencapai komunikasi yang disepakati dengan tujuan secara bersama.

Dalam konteks komunikasi, bahasa menjadi faktor penting sekali dalam upaya untuk mencapai suatu komunikasi dengan yang lain. Setiap manusia tentunya memiliki bahasa dalam menjalin komunikasi dengan yang lain. Bahasa menjadi salah satu mediator paling utama dalam menemukan eksistensi dirinya. Sehingga hakekat manusia menjadi individu dan makhluk sosial menjadi sangat berarti bagi lainnya. Untuk memahami diri, tidak hanya diperlukan dasar berpikir saja. Akan tetapi, diperlukan tindak berbicara sebagai bahasa, dan alat untuk mengkomunikasikan diri dengan yang lain.

Meski demikian, Habermas dalam konteks individu, sebagai hakekat manusia di Barat, berupaya mengkritik modernitas, di Barat. Sedangkan, individu dalam komunitarian orang timur itu adalah individu yang kolektif, dalam arti bahwa penegasan itu sebenarnya Habermas ingin menawarkan sebuah praksis komunikasi, sehingga individu yang diskursif yang mampu bertindak dalam tataran praksis komunikasi. Dalam konteks masyarakat modern ini saat ini yang beragam dan sangat plural, yang di dalamnya setiap individu-individu terlibat dalam bermasyarakat. Karakter dari masyarakat modern ini yang kalau boleh dikatakan sebagai bentuk penindasan dan kapitalistik inilah yang dikritik oleh Habermas. Sudah seharusnya keberadaan manusia harus dilihat bagaimana pada cara penyampaiaan komunikasi untu diterima kebenaranya.

Habermas mencoba memahami, bahwa masyarakat modern sangat liberal, yang mana individu-individu ini dibayangkan sebagai yang terlepas dari identitatas budaya. Individu-individu hanya dilihat sebagai suatu anggota masyarakat. Habermas memetakan individu sebagai individu liberal dan individu komunitarian. Individu liberal itu adalah bagian pemikiran orang-orang Barat. Sedangkan, inividu komunitarian itu

${ }^{6}$ F Budi Hardiman, Menuju Masyarakat Komunikatif : Ilmu, Masyarakat, Politik dan Postmodernisme Menurut Jurgen Habermas, Kanisius, Yogyakarta, 2009, hlm: 125. 
adalah dari pemikiran Timur. Dalam konteks ini, untuk menjembatani individu liberal dan individu komunitarian, Habermas menawarkan individu diskursif. Individu diskursif ini ingin meraih identitasnya tidak dari dirinya sendiri, tapi dalam proses pembentukan identitas baru yang dibangun bersama secara diskursif ${ }^{7}$.

Dalam upaya menemukan suatu proses pembentukkan jati diri manusia yang baru, Habermas menawarkan lewat berbahasa secara kompeten atau komunikasi dengan tujuan bahwa penggunaan cara komunikasi sangatlah tepat sekali dengan standar secara rasional. Dalam upaya mencapai identitas baru itu Habermas memberikan empat klaim, yang berkaitan dengan, kebenaran (wahr), ketepatan (richtiq), dan kejujuran $\left(\right.$ wahrhaftig $^{8}$. Jadi, jika sesuai dengan syarat-syarat itu akan terbentuk konsensus tentang kesahihan ucapan-ucapan tertentu beserta pengandaian-pengandaian yang terkandung di dalamnya, menurut Habermas konsensus seperti itu memiliki pendasaran rasional. Jadi, ucapan-ucapan betul-betul boleh disebut benar, bila di antara para peserta diskusi terdapat menurut syarat syarat "situasi percakapan yang ideal". 9 .

Habermas berpendapat, bahwa sebelum proses rasionalisasi ini, terdapat identitas antara dunia kehidupan (lebenswelt) dan sistem yang dalam masyarakat tradisional tentu saja masih sederhana dan sedikit terdiferensiasi. Dalam keadaan ideal menurut Habermas Lebenswelt itu berkembang dalam bentuk rasionalitas komunikatif yang semakin diskursif, sementara itu, sistem berkembang dalam bentuk kompleksitasnya ${ }^{10}$.

Paradigma komunikasi yang diusung oleh Jurgen Habermas, makna komunikasi bisa juga diartikan sebagai interaksi. Dengan interaksi, dia mencoba menjelaskan bahwa tindakan komunikasi, interaktif simbolis. Tindakan komunikatif itu ditentukan oleh norma-norma konsensual, yang mengikat, yang menentukkan harapan-harapan timbal balik mengenai tingkah laku dan yang harus dimengerti dan diketahui sekurangkurangnya oleh dua subjek yang bertindak. Norma-norma sosial diberlakukan lewat sanksi-sanksi. Makna dari norma-norma itu diobjektifkan dalam komunikasi lewat bahasa sehari-hari. Sementara kesahihan proposisi-proposisi yang secara analitis tepat dan secara empiris benar, kesahihan norma-norma sosial didasarkan hanya dalam

\footnotetext{
${ }^{7}$ F Budi Hardiman, Filsafat Fragmentaris: Deskripsi, Kritik, dan Dekonstruksi, Kanisius: Yogyakarta, 2007, hlm: 130.

${ }^{8}$ F Budi Hardiman, Demokrasi Deliberatif : Menimbang Negara Hukum dan Ruang Publik Dalam Teori Diskursus Jurgen Habermas, Kanisius, Yogyakarta, 2009, hlm: 37.

${ }^{9} \mathrm{~K}$ Bertens, Filsafat Barat Kontemporer Inggris-Jerman, Gramedia, Jakarta, 2002, hlm:248.

${ }^{10} \mathrm{~F}$ Budi Hardiman, Demokrasi Deliberatif : Menimbang Negara Hukum dan Ruang Publik Dalam Teori Diskursus Jurgen Habermas, Kanisius, Yogyakarta, 2009, hlm: 42.
} 
intersubjektifitas saling pemahaman maksud-maksud yang dijamin oleh pengetahuan umum mengenai kewajiban-kewajiban ${ }^{11}$.

\section{Evolusi Sosial dan Identitas Ego}

Paradigma komunikasi yang diusung oleh Habermas, sebagai individu diskursif, tentunya tidak bisa dilepaskan dari interaksi sosial. Dalam upaya untuk mencapai pemahaman komunikasi dibutuhkan rasionalitas yang tepat, jujur dan benar. Dalam tataran rasionalisasi dengan menggunakan teori sosial, Habermas mencoba mengkritik keberadaam masyarakat modern, yang cenderung hidup dengan hedonisme dan konsumerisme.

Untuk mengatasi masalah yang dihadapi masyarakat modern. Habermas menemukan ciri komunikatif pada peran sosial, dengan peran sosial. Diharapkan tingkah laku yang berbeda dapat dihubungkan sehingga terbentuklah sistem motivasi timbal balik. Dalam peran sosial, diandaikan tiga hal. Pertama, para partisipan interaktif dapat mengandaikan perspektif lainnya. Kedua, para partisipan interaksi memiliki cakrawala waktu yang melampui konsekuensi tindakan langsung. Ketiga, motif tindakan partisipan dikendalikan lewat mekanisme sanksi ${ }^{12}$.

Habermas mencoba membuat tiga tahap perkembangan kompetensi komunikatis dalam konteks sosial. Pertama, pada tahap interaksi melalui simbol-simbol, tuturan dan tindakan masih terkait dalam kerangka kerja sebuah bentuk komunikasi tunggal yang bersifat memerintah. Kedua, pada tahap tuturan yang dideferensiasikan dengan pernyataan-pernyataan. Pernyataan ini dianggap sebagai bagian tingkah laku dari speech, sehingga mampu menghasilkan klaim-klaim komunikasi yang tepat untuk mencapai komunikasi secara sosial ${ }^{13}$.

Berpijak dari perkembangan konteks sosial, dengan menggunakan paradigma komunikasi secara sosial, ini ditujukan bahwa individu, tak bisa dilepaskan dengan sosial-masyarakat, syarat-syarat itu merupakan bagian bahasa sebagai mediator dalam upaya menyampaikan komunikasi melalui simbol dan tutur untu menemukan hakekat manusia, sebagai mahkluk yang komunikatif. Komunikatif dalam konteks sosial, adalah

\footnotetext{
${ }^{11}$ F Budi Hardiman, Kritik Ideologi: Menyingkap Pertautan Pengetahuan dan Kepentingan Bersama Jurgen Habermas, Kanisius, Yogyakarta, 2009, hlm: 96.

${ }^{12}$ F Budi Hardiman, Masyarakat Komunikatif : Ilmu, Masyarakat, Politik dan Postmodernisme Menurut Jurgen Habernas, Kanisius, Yogyakarta, 2009, hlm: 126.

${ }^{13} \mathrm{~F}$ Budi Hardiman, Ibid, hlm : 65.
} 
kritik yang ingin dilakukan oleh Habermas, dalam memberangus nilai-nilai modernitas yang justru membelenggu manusia, sehingga individu harus menghadirkan eksistensinya lewat komunikasi atas klaim-klaim kebenaran.

Namun demikian, ada hal yang mungkin jangan kita lewatkan di dalam individu itu menyimpang identitas ego. Identitas ego ini adalah cara eksistensi manusia bisa melebur dengan masyarakat sosial untuk mencapai komunikasi. Konsep identitas ego dalam pikiran Habermas ini ingin mencapai makna hidup yang berarti dalam hubungan komunikasi dengan yang lain. Identitas ego merupakan simbol organisasi sosial atas klaim-klaim ego ${ }^{14}$.

Dalam konteks individu, setiap individu, pada awal nya memiliki hal yang berbeda dengan yang lain, secara umum, terkadang identitas ego ini memiliki pada secara universal dalam hubungan dengan yang lain, tetapi secara individual memiliki hal yang berbeda. Identitas ego menjadi salah faktor paling siginifikansi sekali dalam upaya mengkonstruk kemampuan manusia agar lebih dewasa, untuk mengatasi situasi konflik dalam masyarakat sosial, sehingga melahirkan hubungan yang harmoni melalui komunikasi. Dengan adanya, identitas ego dalam diri manusia, maka ia akan menciptakan organisasi sosial yang baik dalam interaksi dengan masyarakat

Dengan identitas ego, individu bisa mengembangkan kognitif dan motivasinya dalam interaksi sosial, sehingga bisa bentuk bentuk di dalam setiap identitas diri manusia, dengan tujuan mencapai pemahaman yang sama. Dalam mengatasi masalah modernisasi, seperti individu-individu yang hanya dibungkam oleh budaya kapitalisme dan konsumerisme serta hedonisme. Hal itu sebagaimana dikatakan oleh Habermas:

Consumerism and possesive individualism, motive of performance and competition gain the force to shape conduct. The communicative practice of everday life is one sidedly rationalized into specialist-utilitarian lifestyle; and this media-induced shift to purposive-rational action orientations calls forth the reaction of hedonisme freed from presures of rationality. ${ }^{15}$

Pernyataan di atas menegaskan bahwa upaya rasionaliasi dalam praktek komunikasi sangat dibutuhkan dalam diri manusia, untuk mengatasi setiap individu yang hedonisme. Dengan adanya komunikasi secara praktis mampu memberikan

\footnotetext{
${ }^{14}$ Jurgen Habermas, Communication and the Evolution Society, Translated by Thomas McCarthy, Beacon Press, Boston, 1976, hlm: 72.

15 Jurgen Habermas, The Theory of Communicative Action Volume 1 Reason and The Rationalization of Society, Translated by Thomas McCarthy, Beacon Press, Boston, 1984, hlm :xxiv.
} 
kesadaran pada invidiviu bahwa tindakan hedonisme itu adalah hal yang tidak tepat, dalam konteks masyarakat sosial dan praktek konsumerisme yang telah diracuni oleh modernisasi.

Tindakan komunikasi itu muncul karena dilandasai oleh kesadaran diri dalam mencapai upaya rasionalisasi. Tindakan komunikasi sebagai rasionalisasi ini dimaksudkan oleh Habermas sebagai cara untuk menseleksi bagian-bagian dari moral, dan kesadaran dalam membangun hubungan sosial sebagai bentuk dari tanggung jawab, yang mana tindakan rasionalisasi itu muncul karena terdapat kesahihan dan kebenarankebenaran yang memang harus dilakukan, dalam bentuk ekspresi dan norma-norma kebenaran.

Habermas berpendapat bahwa rasionalisasi dalam bidang interaksi sosial itu tidak sama dengan rasionalisasi dalam bidang kerja. Rasionalisasi dalam bidang interaksi, itu pada dirinya sendiri tidak akan membawa perbaikan fungsi sistem masyarakat, tetapi akan memperlengkapi para anggota masyarakat dengan kesempatan bagi emansipasi yang lebih jauh lagi dan proses individuasi yang progresif. ${ }^{16}$

Habermas, memberikan catatan, bahwa identitas ego menjadi salah satu pusat kemampuan untuk memberikan kesadaran pada tiap individu, di bawah kondisi sebagai komunikasi secara intersubjektif. Momen secara universal adalah bagian dari proses refleksi untuk menghubungkan pada individu-individu pada aspek afektif dan praktis secara alami, sehingga identitas ego bisa dijadikan sebagai landasan filosofis dalam upaya kritik terhadap sikap diri sendiri. ${ }^{17}$

Dengan demikian, identitas ego dalam diri manusia menjadi sangat urgen dalam upaya mendorong diri manusia sebagai hakekat manusia, agar tidak bersikap pada tataran individualitas. Itulah kritik yang diajukan Habermas, sehingga dengan memunculkan kritik terhadap diri sendiri, bisa membangun komunikasi dengan yang lain. Dalam hal ini, identitas ego di munculkan agar tiap-tiap individu bisa meleburkan setiap kepentingan -kepentingan manusia dalam kepentingan secara bersama, dengan syarat-syarat yang telah ditentukan dalam komunikasi, misalnya masalah, kebenaran, kejujuran dan ketepatan melanikan juga validitas klaim.

\footnotetext{
${ }^{16}$ F Budi Hardiman, Kritik Ideologi: Menyingkap Pertautan Pengetahuan dan Kepentingan Bersama Jurgen Habermas, Kanisius, Yogyakarta, 2009, hlm: 108.

17 Jurgen Habermas, The Theory of Communicative Action Volume 1 Reason and The Rationalization of Society, Translated by Thomas McCarthy, Beacon Press, Boston, 1984, hlm :xxiii.
} 
Dengan berpijak pada hal tersebut, sebenarnya teori evolusi sosial dengan meleburkan identitas ego untuk kepentingan bersama itu tujuanya adalah untuk mengatasi perbedaan antara proses belajar, di satu pihak proses-proses belajar teknis yang membawakan penguasaan alam lebih besar dan belajar teknis yang meningkatkan produktivitas kerja dan di lain pihak proses-proses belajar komunikatif yang menghasilkan perbaikan kualitas komunikatif dari relasi-relasi di antara manusia. ${ }^{18}$

\section{Refleksi Tindakan Komunikatif Menuju Masyarakat Komunikatif}

Dalam konteks masyarakat modern, Jurgen Habermas, mengandaikan bahwa masyarakat ini diandaikan sebagai masyarakat yang komunikatif. Masyarakat komunikatif bukanlah masyarakat yang melakukan kritik melalui revolusi atau kekerasan, melainkan lewat argumentasi, yaitu perbincangan atau diskursus (discourse) dan kritik. Oleh sebab itulah, Habermas mengusahakan dasar-dasar kerjasama sosial bagi masyarakat pluralistik modern menjadi, perhatian Habermas adalah bagaimana bisa dicapai konsensus rasional bila terjadi konflik dalam masyarakat pluralistik modern. Sebab apa, kehidupan masyarakat modern menyimpan banyak konflik sosial, hukum, ekonomi dan budaya. Sehingga diperlukan suatu penyelesaiaan dalam mengatasi problem modernitas dengan sebuah tindakan yang lebih komunikatif.

Cara yang tepat untuk mengatasi masalah modernitas yakni kita melakukan diskursus dengan mengandaikan kemungkinan untuk mencapai konsensus rasional. Diskursus untuk mencari konsensus atas klaim kebenaran disebut teoretis, sedangkan untuk mencapai konsensus atas klaim ketepatan disebut "diskursus praktis"19. Diskursus-diskursus melalui argumentasi itu menegaskan bahwa pada hakekatnya manusia dalam kehidupan bermasyarakat tidak bisa dilepaskan, dalam berkomunikasi, komunikasi atau makhluk yang berbicara itu menjadi tuntutan zaman saat ini, tidak boleh diam saja.

Dengan demikian, tindakan komunikasi dan tindakan strategis secara praktis adalah hal yang paling mutlak harus dilakukan oleh setiap individu-individu manusia dengan tujuan untuk sebuah interaksi sosial. Dalam pandangan Habermas, suatu tindakan Komunikatif dan tindakan stratetgis, memiki kaitan untuk mencapai

\footnotetext{
${ }^{18} \mathrm{~K}$ Bertens, Filsafat Barat Kontemporer Inggris-Jerman, Gramedia, Jakarta, 2002, hlm: 249.

${ }^{19}$ F Budi Hardiman, Menuju Masyarakat Komunikatif : Ilmu, Masyarakat, Politik, dan Postmodernisme Menurut Jurgen Habermas, Kanisius, Yogyakarta, 2009, hlm : 18.
} 
komunikasi yang tepat. Tindakan strategis ini bersifat terbuka dan tertutup. ${ }^{20}$ Oleh karena itu, tindakan Komunikatif dan tindakan strategis bisa berjalan dengan dasar rasionalitas. Rasio komunikatif inilah yang menjadi dasar pijakan manusia dalam mengkomunikasikan dengan melihat pada diri individu dalam konteks masyarakat modern. .

Dengan demikian, rasionalitas komunikatif ini mengarahkan pada manusia menghilangkan praktek-praktek kekuasaan dalam pengetahuan dan upaya melakukan kritik atas modernitas yang seungguhnya kehadiran dunia kehidupan, seharusnya bisa di maknai secara nyata, bahwa upaya rasionalisas dari tindakan komunikatif akan menghasilkan beberapa hal. Pertama, terciptanya integrasi sosial yang menjamin bahwa dalam situasi-situasi yang baru, koordinasi tindakan tetap terpelihara melalui sarana hubungan-hubungan antarpribadi yang diatur secara legitim dan stabilitas identitasidentitas kelompok tetap terjaga. Dengan adanya tindakan komunikasi melalui pengertian dan pemahaman, mungkin hakekta manusia akan terperlihara dan harmoni, dengan komunikasi. Kedua, sosialiasasi yang menjamin bahwa bertindak bagi generasi mendatang tetap terjamin dan penyelarasan sejarah hidup individu dan bentuk kehidupan kolektif terpelihara ${ }^{21}$.

Dengan berpijak, pada kedua hal tersebut, proses rasionalisasi melalui tindakan komunikasi akan semakin meneguhkan identitas setiap individu-individu dari berbagai ego, untuk bisa memahami bahwa masalaha yang terkait dengan modernitas itu harus di capai dengan "paradigma komunikasi". Jadi, hakekat manusia itu ditentukan pada makhluk yang berbicara atau manusia yang komunikatif di tengah-tengah kehidupan sosial. Oleh karena itu, Habermas menginginkan bahwa individu individu harus bersikap komunikatif untuk menuju masyarakat komunikatif, yang dilandasi atas rasionolaitas, karena manusia adalah makhluk yang berpikir, sekaligus mahkluk komunikatif.

\footnotetext{
${ }^{20}$ F Budi Hardiman, Kritik Ideologi : Menyingkap Pertautan Pengetahuan dan Kepentingan Bersama Jurgen Habermas, Kanisius, Yogyakarta, 2009, hlm: 99.

${ }^{21}$ F Budi Hardiman, Menuju Masyarakat Komunikatif: Ilmu, Masyarakat, Politik, dan Postmodernisme Menurut Jurgen Habermas, Kanisius, Yogyakarta, 2009, hlm: 254.
} 


\section{D.SIMPULAN}

Dari pembahasan di atas dapat disimpulkan bahwa manusia sebagai individu, pada hakekatnya, tidak hanya berkutat untuk mereleksikan mengenai hakekat diri manusia, bertanya tentang diri manusia? Akan tetapi, hakekat manusia saat ini lebih menekankan bagaimana tiap-tiap individu itu hadir di tengah-tengah masyarakat modern bisa melakukan dengan cara komunikatif. Individu-individu manusia menemukan keunikan dan kepribadian jika mampu bersikap komunikatif, sikap komunikatif ini terlahir dari rasionalitas yang di gagas oleh Jurgen Habermas. Individu yang komunikatif sangat penting sekali. Habermas memperlihatkan bahwa rasionalisasi dunia kehidupan ini adalah rasionalisasi yang seimbang pada tindakan rasional, dengan tujuan tindakan komunikatif. Dalam upaya mencapai suatu pemahaman-pemahaman atas persoalan modernitas.

Oleh Karena itu, keberadaan Individu komunikatif inilah yang menjadi hakekat manusia dalam kajian filsafat manusia, manusia menjadi ada, bila manusia itu mampu bersikap komunikatif. Komunikatif dalam artian untuk melakukan kritik-kritik atas keberadaan masyarakat modern yang cenderung konsumerisme dan hedonisme yang tidak sesuai dengan norma sosial. Ruang Publik menjadi hal nyata untuk menyampaikan aspirasi melalui cara komunikatif, dengan syarat syarat tertentu yakni ketepatan, kejujuran dan kebenaran.

Dengan demikian, eksistensi manusia dalam kehidupan masyarakat, ditentukan oleh individu-individu yang aktif bersikap komunikatif sebagai upaya dalam mencapai komunikasi, filosofi manusia dalam zaman modern harus mampu bersikap komunikatif, tidak hanya diam saja, dalam menghadapi masalah modernitas, yang berkaitan dengan industri,dan teknologi serta budaya konsumerime. Dalam posisi ini, identitas ego bermain dalam artian untuk berkomunikasi antar pribadi, tidak hanya menekankan pada individu saja, Individu komunikatif inilah yang menjadi bagian dari individu diskursif untuk menuju masyarakat komunikatif. Oleh karena itu, keberadaan aktual manusia dalam pemikiran Habermas adalah individu yang komunikatif. 


\section{DAFTAR PUSTAKA}

Adelbert Snijdelrs OFC Cap. Antropologi Filsafat Manusia Paradoks dan Seruan. Kanisius: Yogyakarta. 2004.

F Budi Hardiman. Menuju Masyarakat Komunikatif: Ilmu, Masyarakat, Politik dan Postmodern Menurut Jurgen Habermas. Kanisius: Yogyakarta. 2009.

F Budi Hardiman. Demokrasi Deliberatif: Menimbang Negara Hukum dan Ruang Publik Dalam Teori Diskursus Jurgen Habermas. Kanisius, Yogyakarta. 2009.

F Budi Hardiman. Kritik Ideologi: Menyingkap Pertautan Pengetahuam dan Kepentingan Bersama Jurgen Habermas. Kanisius: Yogyakarta. 2009.

F Budi Hardiman, Filsafat Fragmentaris: Deskripsi, Kritik dan Dekontruksi. Kanisius: Yogyakarta. 2007.

Franz Magnis Suseno. Pijar-Pijar Filsafat: Dari Gatholoco ke Filsafat Perempuan, Dari Adam Muller ke Postmodernisme. Kanisius: Yogyakarta. 2005.

Jurgen Habermas. Communication and the Evolution of Society, Translated by Thomas McCarthy. Beacon Press: Boston. 1979.

Jurgen Habermas. The Theory of Communicative Action Volume 1 Reason and the Rationalization of Society, Translated by McCarthy. Beacon Press: Boston. 1984.

Jurgen Habermas. The Theory of Communicative Action, Volume 2, LifeWorld and System: A Critique of Functionalist Reason,Translated by McCarthy. Beacon Press: Boston. 1987.

K Bertens. Filsafat Barat Kontemporer Inggris-Jerman. Gramedia, Jakarta. 2002.

Lorens Bagus, Kamus Filsafat. Gramedia, Jakarta. 2000. 